\title{
Volatile compounds and quality analysis in commercial medicinal plants of Camellia sinensis
}

\author{
Joyce Castro de Menezes ${ }^{1}$ (i) Gabriela Borba Vilela Borges ${ }^{1}$ (iD) Fátima de Cássia Oliveira Gomes ${ }^{1}$ \\ Mariana de Lourdes Almeida Vieira ${ }^{1}$ (i) Andréa Rodrigues Marques ${ }^{2}$ \\ Ana Maria de Resende Machado ${ }^{1^{*}}$ (iD
}

${ }^{1}$ Departamento de Química, Centro Federal de Educação Tecnológica de Minas Gerais (CEFET-MG), 30421169, Belo Horizonte, MG, Brasil. E-mail: anamrmachado@cefetmg.br. "Corresponding author.

${ }^{2}$ Coordenação de Ciências, Centro Federal de Educação Tecnológica de Minas Gerais (CEFET-MG), Belo Horizonte, MG, Brasil.

ABSTRACT: The interest in the use of green tea (Camellia sinensis) (L.) Kuntze (Theaceae) products have increased in the last few years due to its medicinal properties. In the present study, we proposed that headspace solid phase microextraction, in combination with gas chromatography coupled to mass spectrometric could be an efficient method to assess the volatile compounds and to ensure the quality control of $C$. sinensis. We have also compared the anatomical leaf of different commercial green tea samples, analyzed the information in their labels and determined the presence of foreign materials, moisture content, total ashes and microorganisms. Among the 30 analyzed samples, six were identified as C. sinensis according to the anatomical study; $83.4 \%$ were not in accordance with the specified limits for foreign matter and $6.6 \%$ for moisture content. All samples presented total ashes in accordance with the current legislation. The analysis indicated the presence of several different volatile organic compounds, being terpenes, hydrocarbons and alcohols the major ones. Microbiological analysis showed that $13.3 \%$ and $16.6 \%$ of the samples exceeded the limits for counts of molds and yeasts, and for mesophilic bacteria, respectively. $73.3 \%$ presented E. coli above the established sanitary limits.

Key words: green tea, GC-MS, SPME, quality control.

Caracterização dos compostos voláteis e análise da qualidade de plantas medicinais comerciais de Camellia sinensis

RESUMO: O interesse no chá verde comercial (Camellia sinensis) (L.) Kuntze (Theaceae) tem aumentado nos últimos anos devido suas propriedades medicinais. No presente estudo utilizamos a microextração em fase sólida, em combinação com a cromatografia gasosa acoplada com espectrometria de massas, como um eficiente método de caracterização de compostos voláteis e efetuamos o controle de qualidade de C. sinensis. Comparamos também a anatomia das folhas de diferentes amostras comerciais de chá verde, as informações de seus rótulos e determinamos a presença de matérias estranhas, de microrganismos, o teor de umidade e de cinzas totais. Entre as trinta amostras analisadas, seis foram identificadas como C. sinensis de acordo com o estudo anatomico; 83,4\% não estavam de acordo com os limites especificados para matérias estranhas e 6,6\% para o teor de umidade. Todas as amostras apresentaram cinzas totais de acordo com a legislação vigente. As análises evidenciaram diversos compostos orgânicos voláteis distintos, sendo majoritários terpenos, hidrocarbonetos e álcoois. As análises microbiológicas mostraram que 13,3 e 16,6\% das amostras excedeu os limites de contagem para bolores e leveduras, e para bactérias mesófilas, respectivamente. Por fim, 73,3\% das amostras apresentou Escherichia coli acima dos limites sanitários estabelecidos.

Palavras-chave: chá verde, CG-EM, MEFS, controle de qualidade.

\section{INTRODUCTION}

Green tea (Camellia sinensis) (L.) Kuntze (Theaceae) is a non-fermented tea, widely consumed in the world and especially popular in almost all Asian countries (LIN et al. 2012). Studies indicated that consumption of $C$. sinensis is associated with low risk of various types of cancer, increased insulin activity, antimicrobial capacity, anti-inflammatory properties, as well as it may confer protection against cardiovascular and cerebral diseases (SILVA et al., 2013; THITIMUTA et al., 2017),

Camellia sinensis is a small shrub-like plant, simple-entire leaves with serrated margin and leather-like texture. Leaf morphology and anatomy have always played an important role in plant taxonomy, particularly for identifying taxa. Unicellar tectonic trichomes and calcium oxalate druses and sclereids allow the anatomical identification of $C$. sinensis leaf of teas (DUARTE \& MENARIM, 2006). 
C. sinensis tea can be classified into six different types based on different processing methods employed, such as white tea, green tea, oolong tea, black tea, yellow tea, and dark tea (ZHAO et al., 2011). Various green teas are available to consumers that represent different processing methods, storage conditions, harvest times, season, climatic conditions of cultivation, plant varieties and growing regions, all of which may contribute to different aroma characteristics in each tea. (GUPTA \& KUMAR, 2017; LEE et al., 2013; LI et al., 2017).

The taste and flavor of teas are controlled by key chemical components, which are volatile compounds that are directly correlated with their qualitative and quantitative composition. In general, fresh green tea leaves contain high levels of polyphenols, as the major responsible for the biological properties of the plant (HUANG et al., 2018). Volatile organic compounds produced as secondary metabolites in plants include terpenoids and terpenes, phenylpropanoids and oxygenated compounds and nitrogen compounds (PRIPDEEVECH \& MACHAN, 2011). Volatile compounds in green teas extracted with solvents have been studied extensively using gas chromatography-mass spectrometry (GC-MS) to understand the differences in green tea aromatic components. SPME is a convenient technique because there is no complicated sample preparation; it is fast and environmentally friendly once it does not require any solvents and a convenient method for the analysis of volatile compounds in tea (LV et al., 2012).

Authenticity of commercial products is a major challenge for quality control. Some products can be adulterated with other species or do not meet their label specifications. Therefore, it is necessary to standardize raw materials to maintain the uniformity of quality, safety and efficacy. It is important to ensure a good quality product free of potentially harmful microorganisms. Microbial contamination of a product can cause changes in their chemical properties, and further characterize disease risk to the user. Consequences of this damage are associated with loss of therapeutic efficacy by degradation of the active principle (FARMACOPÉIA BRASILEIRA, 2010).

The aims of this study were to evaluate the chromatographic profile of volatile compounds and to compare the anatomical leaf and volatile compounds of different commercial samples of green tea, which may allow the identification of these medicinal herbs. We have also analysed the information provided in the labels and determined the presence of foreign materials, moisture content, total ash and microorganisms to assess whether such items were in accordance with the sanitary legislation.

\section{MATERIALS AND METHODS}

\section{Plant material}

Leaves of Camellia sinensis (L.) Kuntze (Theaceae) were collected from Parque Estadual do Itacolomi, located in the municipality of Mariana and Ouro Preto, in south-eastern of Minas Gerais State, Brazil, in August 2014. Dried species of $C$. sinensis were deposited in the herbarium of the Instituto de Ciências Biológicas of Universidade Federal de Minas Gerais (UFMG), under the 181990 code. Samples of these plants in natura were immediately employed in the anatomy analysis. The remaining part of each sample was dehydrated in a drying oven with ventilation at $35^{\circ} \mathrm{C}$ and used in the other analysis.

\section{Analysis of commercial plants samples}

Thirty commercial herbs of Camellia sinensis were randomly sampled from herb-traders in commercial establishments in Belo Horizonte-MG, Brazil. Three packing units were purchased from each commercial market and inspected in terms of their packaging and labelling. It was determined the presence of foreign material in the samples, moisture content and total ash, and also microbial tests were performed (FARMACOPÉIA BRASILEIRA, 2010).

\section{Leaf anatomy analysis}

Leaf samples of plants in natura were fixed in ethanol $70^{\circ} \mathrm{GL}$ (JENSEN, 1962). Dry leaves of the commercial samples selected from packaging unit from each commercial market were rehydrated in water that was slightly heated with $20 \%$ glycerin for $60 \mathrm{~min}$. Sections of the leaf blade (in natura and rehydrated leaves) were cleared with sodium hypochlorite $(\mathrm{NaClO})$ solution at $20 \%$ until depigmentation of the leaves was observed and then washed with water. After removal of mesophyll tissues, pieces of epidermis were obtained and then dehydrated in an alcohol series and stained with astrablau-safranin (JENSEN, 1962) and then assembled into semi-permanents slides. Hand-cut transverse sections were made and stained with astrablau-safranin (JENSEN, 1962). Leaf epidermal and transverse sections from three different individual plants of each sample were analyzed. Histological observations were performed using an Olympus BX53 microscopic, and micrographs were obtained. Anatomical features of the leaves were analysed as described by DUARTE \& MENARIM (2006). 


\section{Determination of moisture content}

For determination of moisture content,

$3 \mathrm{~g}$ of the samples were weighed in pre-weighed crucibles, which were heated in an oven at $120^{\circ} \mathrm{C}$. Crucibles were then removed from the oven, cooled in a desiccator to room temperature, and weighed. Heating, cooling and weighing were repeated until the weight became constant (BRANDÃO et al., 2006; FARMACOPÉIA BRASILEIRA, 2010).

\section{Determination of ash content}

Samples used to determine the moisture content were maintained in the dish at $500^{\circ} \mathrm{C}$ for approximately 3 hours. After cooling to room temperature, they were weighed, and the total ash content was obtained by the difference in mass of the samples after and before calcination (BRANDÃO et al., 2006; FARMACOPÉIA BRASILEIRA, 2010).

\section{Microbiological analysis}

The microbial tests followed the FARMACOPÉIA BRASILEIRA COMPENDIUM (2010).These tests included the following: counting both the total and thermotolerant coliforms using the multiple tube method; detection of Salmonella spp. with Selenite-Cystine (Acumedia, USA) and Rappaport-Vassiliadis broth (Acumedia, USA) for the selective enrichment stage, as well as SalmonellaShigella Agar (Himedia, India) and HecktoenEnteric Agar (Himedia, India) for the selective plate method; and yeast counts with malt extractyeast extract agar $(0.3 \%$ malt extract, $0.3 \%$ yeast extract, $0.5 \%$ peptone, $1 \%$ glucose, $2 \%$ agar, $0.02 \%$ chloramphenicol). Mesophilic bacterial counts were performed using the spread-plate technique in Plate Count Agar (Himedia, India).

\section{Chromatographic analysis}

For the SPME analysis, samples from fresh and drying leaves were cut, and $2.0 \mathrm{~g}$ of the samples was placed in a glass vial containing $5 \mathrm{~mL}$ of the water and $3 \mathrm{~g}$ of $\mathrm{NaCl}$. This solution was hermetically closed with a Teflon septum and aluminium cap in a $20-\mathrm{mL}$ vial and heated for $10 \mathrm{~min}$ at $70^{\circ} \mathrm{C}$ under stirring. The SPME device was then inserted into the sealed vial by manually penetrating the septum, and the fiber (PDMS-DVB-CAR Supelco, Bellefonte, PA, USA) was exposed to the headspace of the plant material during $30 \mathrm{~min}$ at $70^{\circ} \mathrm{C}$. After extraction, the needle on the SPME manual holder was set into the GC injector, and the fiber was directly exposed to the hot injector at $250^{\circ} \mathrm{C}$ for $15 \mathrm{~min}$ in the splitless mode. This procedure was adapted from Lee et al. (2013). Plants samples were analysed on a Gas Chromatograph (Agilent Technologies 7890A GC System) coupled with Mass Spectrometer (Agilent 5975C inert MSD Triple-Axis Detector) using solidphase microextraction. A series of alkanes (C8-C20) were analysed using the same method to identify the compounds through comparisons with the literature, either from the National Institute of Standards and Technology (NIST) library. The column employed was a HP5-MS column (length of 30m I.D. of 0.25 , and film thickness of $0.25 \mu \mathrm{m})$. The oven temperature program commenced at $35^{\circ} \mathrm{C}$, maintained for $0.5 \mathrm{~min}$ and was increased to $150^{\circ} \mathrm{C}$ maintained for $1 \mathrm{~min}$ at a rate of $1.4^{\circ} \mathrm{C} / \mathrm{min}$, after a ramp rate of $5^{\circ} \mathrm{C} \mathrm{min}^{-1}$ at $250^{\circ} \mathrm{C}$ maintained for $1 \mathrm{~min}$ with and the flow rate of helium was $1.4 \mathrm{~mL} / \mathrm{min}$. Characterization of tentatively identified compounds from the NIST library and by the Kovats retention indices calculated for each peak with reference to the n-alkane standards running under the same conditions. Peaks were assigned when the similarity was above $80 \%$. Any known artificial peaks were excluded from the data set. Relative percentages of various components in the samples were obtained by peak area normalization.

\section{RESULTS AND DISCUSSION}

\section{Evaluation of commercial herbs}

Our data showed that the labels on the packages in which herbs of $C$. sinensis species were marketed did not contain information regarding their scientific name (43\%), contraindications and indications $(60 \%)$, instructions for use $(60 \%)$, and parts of the plant material that were used $(80 \%)$. We have reported; however, that $100 \%$ of the evaluated labels exhibited expiration date and a batch number. This analysis showed that herb suppliers usually do not make an effort to normalize the data of the plants on their packages.

Label of a product shall not contain false or insufficient information that misleads the consumer. Nor can medicinal properties be attributed without a scientific evidence. According to the legislation, any information that is directly or indirectly attributed to a therapeutic indication is not allowed. In this study, among the analyzed samples, $10(33 \%)$ contained information on therapeutic properties such as "digestive, diuretic, depurative", not meeting what is established by law. Moreover, it was observed that commercial establishments did not comply with FARMACOPÉIA BRASILEIRA (2010), which specifies the processing and storage conditions and the appropriate parameters to evaluate the quality of the plant material. 
According to our analysis, some irregularities were observed when conditions of material within the packaging were evaluated. Among analysed samples, $13 \%$ presented a mass exceeding that indicated in their package labels. As specified by the pharmacopeia monograph, the percentage of foreign materials in these products should not exceed 2\% (m/m) (FARMACOPÉIA BRASILEIRA, 2010). Nevertheless, it was verified that $83.4 \%$ of the analyzed samples were not in accordance with the specified limits, being the amount of foreign matter present in the samples ranging from $3.30 \%$ to $58.06 \%$ (Table 1 ). These foreign materials consisted of algae, trunks, twigs, seeds, plastic and insects, among others.

These findings are possibly related to an inadequate handling, cleaning and separation of the plant material, being a major problem that has been frequently observed during purity testing in other studies of these kind of marketed products in Brazil. The presence of a high content of foreign matter compromises the quality of the final product, and considerably reduces the amount of vegetal drug available, besides the risk that it may bring to the consumer's health. The moisture content of the samples of $C$. sinensis ranged from $5.7 \%$ to $12.9 \%$ (Table 1 ).

Table 1 - Physical-chemical and microbiological analyzes of Camellia sinensis samples marketed in Belo Horizonte city, Minas Gerais, Brazil.

\begin{tabular}{|c|c|c|c|c|c|c|}
\hline Samples & Foreign material (\%) & Moisture (\%) & Ashes $(\%)$ & $\begin{array}{l}\text { Total mesophilic } \\
\text { bacteria counts } \\
\text { (CFU/g) }\end{array}$ & $\begin{array}{l}\text { Total yeasts and } \\
\text { molds counts } \\
(\mathrm{CFU} / \mathrm{g})\end{array}$ & $\begin{array}{l}\text { Escherichia } \\
\text { coli }(\mathrm{CFU} / \mathrm{g})\end{array}$ \\
\hline 1 & $25.99 \pm 0.5$ & $11.4 \pm 0.5$ & $6.2 \pm 0.1$ & $9.0 \times 10^{2}$ & $3.0 \times 10^{6}$ & - \\
\hline 2 & $37.14 \pm 0.2$ & $11.3 \pm 1.1$ & $5.6 \pm 0.3$ & $7.6 \times 10^{3}$ & - & $3.0 \times 10^{4}$ \\
\hline 3 & $21.10 \pm 0.7$ & $11.8 \pm 0.9$ & $5.7 \pm 0.4$ & $1.2 \times 10^{3}$ & $1.0 \times 10^{1}$ & $1.5 \times 10^{2}$ \\
\hline 4 & $13.71 \pm 0.03$ & $11.2 \pm 0.1$ & $5.7 \pm 0.5$ & $4.0 \times 10^{2}$ & - & $3.0 \times 10^{4}$ \\
\hline 5 & $37.03 \pm 0.05$ & $9.3 \pm 0.1$ & $5.6 \pm 0.3$ & $8.5 \times 10^{2}$ & - & $1.6 \times 10^{2}$ \\
\hline 6 & $25.42 \pm 0.6$ & $9.2 \pm 0.1$ & $4.9 \pm 0.3$ & $1.0 \times 10^{5}$ & $1.7 \times 10^{3}$ & $3.0 \times 10^{4}$ \\
\hline 7 & 0 & $7.1 \pm 0.3$ & $4.7 \pm 0.1$ & $3.0 \times 10^{2}$ & $9.5 \times 10^{1}$ & $1.3 \times 10^{2}$ \\
\hline 8 & $20.24 \pm 0.7$ & $9.3 \pm 0.2$ & $6.0 \pm 0.4$ & $3.0 \times 10^{9}$ & $2.3 \times 10^{2}$ & $3.0 \times 10^{4}$ \\
\hline 9 & $25.40 \pm 0.8$ & $9.5 \pm 0.2$ & $4.2 \pm 0.1$ & $1.0 \times 10^{3}$ & $3.0 \times 10^{1}$ & $3.0 \times 10^{4}$ \\
\hline 10 & $27.51 \pm 0.02$ & $10.9 \pm 1.6$ & $5.7 \pm 0.3$ & $4.0 \times 10^{2}$ & $2.0 \times 10^{1}$ & $3.0 \times 10^{4}$ \\
\hline 11 & $33.97 \pm 0.03$ & $10.4 \pm 0.1$ & $6.4 \pm 0.1$ & $4.5 \times 10^{2}$ & $7.5 \times 10^{1}$ & $2.5 \times 10^{1}$ \\
\hline 12 & $15.84 \pm 0.5$ & $11.1 \pm 1.9$ & $4.5 \pm 0.2$ & $9.6 \times 10^{2}$ & - & $3.0 \times 10^{4}$ \\
\hline 13 & $17.89 \pm 0.8$ & $5.7 \pm 0.1$ & $5.4 \pm 0.2$ & $2.4 \times 10^{4}$ & $1.1 \times 10^{2}$ & $8.0 \times 10$ \\
\hline 14 & $32.87 \pm 0.9$ & $7.1 \pm 0.6$ & $4.8 \pm 0.3$ & $3.0 \times 10^{9}$ & $6.0 \times 10^{1}$ & $3.0 \times 10^{4}$ \\
\hline 15 & $19.78 \pm 0.2$ & $5.7 \pm 0.2$ & $4.7 \pm 0.1$ & $3.0 \times 10^{9}$ & $4.0 \times 10^{1}$ & $3.0 \times 10^{4}$ \\
\hline 16 & 0 & $12.9 \pm 0.1$ & $4.1 \pm 0.1$ & $1.5 \times 10^{2}$ & $1.0 \times 10^{1}$ & $3.0 \times 10^{4}$ \\
\hline 17 & $46.78 \pm 0.8$ & $11.9 \pm 0.1$ & $7.2 \pm 0.1$ & $1.0 \times 10^{3}$ & $5.4 \times 10^{3}$ & $3.0 \times 10^{4}$ \\
\hline 18 & $38.80 \pm 0.1$ & $7.7 \pm 0.6$ & $4.3 \pm 0.3$ & $3.0 \times 10^{1}$ & $3.0 \times 10^{6}$ & - \\
\hline 19 & 0 & $10.7 \pm 0.2$ & $6.7 \pm 0.7$ & $1.2 \times 10^{5}$ & $5.5 \times 10^{1}$ & $3.0 \times 10^{4}$ \\
\hline 20 & 0 & $8.9 \pm 0.1$ & $4.7 \pm 0.5$ & $4.0 \times 10^{2}$ & $1.0 \times 10^{2}$ & $3.0 \times 10^{4}$ \\
\hline 21 & $36.35 \pm 0.6$ & $9.7 \pm 2.0$ & $5.5 \pm 0.3$ & $4.9 \times 10^{3}$ & $4.4 \times 10^{2}$ & $3.0 \times 10^{4}$ \\
\hline 22 & 0 & $6.5 \pm 0.09$ & $3.9 \pm 0.9$ & $3.0 \times 10^{9}$ & $3.0 \times 10^{2}$ & $3.0 \times 10^{4}$ \\
\hline 23 & $43.72 \pm 0.06$ & $7.6 \pm 0.4$ & $4.7 \pm 0.1$ & $1.2 \times 10^{2}$ & $1.3 \times 10^{2}$ & $3.0 \times 10^{4}$ \\
\hline 24 & $58.06 \pm 0.07$ & $9.5 \pm 0.3$ & $5.7 \pm 0.4$ & $2.3 \times 10^{3}$ & $6.0 \times 10^{2}$ & $3.0 \times 10^{4}$ \\
\hline 25 & $52.70 \pm 0.9$ & $10.1 \pm 0.3$ & $6.2 \pm 0.6$ & $1.0 \times 10^{2}$ & $1.1 \times 10^{2}$ & $3.0 \times 10^{4}$ \\
\hline 26 & $3.30 \pm 0.6$ & $6,3 \pm 0,1$ & $3.7 \pm 0.3$ & $2.0 \times 10^{2}$ & $1.5 \times 10^{2}$ & - \\
\hline 27 & $47.03 \pm 0.7$ & $8.7 \pm 0.1$ & $4.9 \pm 0.1$ & $1.2 \times 10^{4}$ & $3.0 \times 10^{6}$ & $3.0 \times 10^{4}$ \\
\hline 28 & $54.18 \pm 0.1$ & $12.5 \pm 1.4$ & $7.5 \pm 0.5$ & $2.7 \times 10^{3}$ & $3.2 \times 10^{2}$ & $3.0 \times 10^{4}$ \\
\hline 29 & $33.47 \pm 0.03$ & $7.3 \pm 0.1$ & $4.2 \pm 0.2$ & $3.0 \times 10^{9}$ & $1.6 \times 10^{3}$ & $3.0 \times 10^{4}$ \\
\hline 30 & $45.08 \pm 0.01$ & $8.2 \pm 0.8$ & $4.9 \pm 0.3$ & $1.4 \times 10^{4}$ & $3.0 \times 10^{6}$ & $3.0 \times 10^{4}$ \\
\hline $\begin{array}{l}\text { Legislation } \\
\text { limits }\end{array}$ & $2 \%$ & $12 \%$ & $8 \%$ & $1 \times 10^{7} \mathrm{CFU} / \mathrm{g}$ & $1 \times 10^{4} \mathrm{CFU} / \mathrm{g}$ & $1 \times 10^{2} \mathrm{CFU} / \mathrm{g}$ \\
\hline
\end{tabular}


The maximum moisture content recommended for this species is $12 \%$. In this research only two samples $(6.6 \%)$ exceeded the established limit (Table 1). Excessive moisture in this kind of product can be damaging to its quality, since it enables enzymatic activity and proliferation of microorganisms that can contaminate the product, decomposing active principles of the plant and producing substances that may cause intoxication if ingested (FARMACOPÉIA BRASILEIRA, 2010). The presence microorganisms in this type of product could also represent a risk to the health of final consumer.

The analysis of total ashes determines the amount of residual non-volatile substances in samples after the removal of the organic substances through incineration process. According to our data, total ashes contents in the analysed samples varied between 3.7 and $7.2 \%$ (Table 1), being all of them in accordance with the FARMACOPÉIA BRASILEIRA (2010) that establishes a maximum limit of $8 \%$. As in the present study, PIMENTEL-SOUZA et al. (2012) analyzed two distinct brands of green tea obtained in Sergipe, Paraná and São Paulo States, Brazil. Two brands of the tea presented values of total ashes below the maximum levels allowed by the specific legislation. SILVA et al. (2013) also analyzed the ash and moisture contents of $C$. sinensis samples commercialized in the city of Araras (São Paulo state, Brazil) and all samples were in compliance with the required moisture and ashes content specification values, ranging from 3 to $8 \%$ for moisture, and from 5 to $7 \%$ for ashes. The amount of total ashes indicated that the preparation and packaging process of these products must ensure that plant material is not mixed with foreign materials, resulting in adulteration of the final product (ARAÚJO et al., 2006).

\section{Anatomical study}

Macroscopic characteristic of $C$. sinensis showed that the leaves are glossy dark green, alternate, short-petiole, coriaceous, lanceolate or elongated-ovate, and roughly serrate as observed to EKAYANTI et al. (2017) (Figure 1A). Mature leaves are bright green coloured smooth, and leathery; while young leaves appear silver because of the covering of short downy hair on the underside. Micromorphological examinations of fresh leaves revealed that the $C$. sinensis present cuticle, epidermis, and mesophyll, crystals of Calcium oxalate, sclereid cell, and trichomes. The type of stomata observed was actinocytic, the variant type of diacytyic stoma with two reniform cells (guard cells), oval or nearly round, regularly surrounded by four or more tangential elongated cells; the stomata were observed only on the lower epidermis. Observation of a transverse cross section of the fresh leaves showed a mesophyll asymmetrical and the presence of sclereid cells and crystals of Calcium oxalate. The sclereid cell is branched, pointed, irregular (often star-shaped) and also can be observed in leaf midrib (Figure 1B).

These anatomical characteristics confirmed the morphological identification of the tea leaf. Effect of dehydration and rehydration on the leaf structures was observed under an optical microscope. After an in fresh sample of C. sinensis was dried, leaves exhibited significant changes in their botanical structures, such as a severe shrinkage of the cuticle, its associated structures, and the underlying epidermal layers. Internally, the crystals of calcium oxalate, sclereid cell remained preserved. The trichomes and stomata were difficult to be observed. All of these characteristics were observed after rehydration of the tea leaf samples. The anatomical criteria based on leaf structures that were used for the identification of tea leaf samples were the presence of sclereids, once these structures were easily visualized after rehydration. Anatomical results showed that only samples 7, 17, 19, 20, 22 and 26 presented sclereid cells and; therefore, were identified as $C$. sinensis.

\section{Chromatographic analysis}

Results of the SPME GC-MS analysis indicated the presence of several different organic compounds, distributed into thirteen classes: terpenes (86), hydrocarbons (31), alcohols (30), aldehydes (26), ketones (17), ethers (6), esters (5), furans (4), lactones (3), norisoprenoids (3), nitrogen compounds (2), carboxylic acid (1) and others (1) (Table 2). Concerning the classes of substances, terpenes (19), followed by aldehydes (15) and alcohols (13) were the three major chemical groups tentatively identified from $C$. sinensis samples in the present study.

Terpenes were the major compounds reported in the analysed samples (Table 2) and they probably play an important role in the tea sensory profile. Terpenes are a large class of vegetable substances, and the most common are monoterpenes and sesquiterpenes (HUANG et al., 2018). High sensitivity of the SPME technique allowed the identification of a greater number of terpene compounds, which are primarily responsible for the formation of the aroma of plants (UENOJO et al., 2007).

As in this study, LIN et al. (2012 reported terpenes as a major chemical group identified by headspace chemical analysis of Longjing tea, the most famous Chinese green tea, as an important 


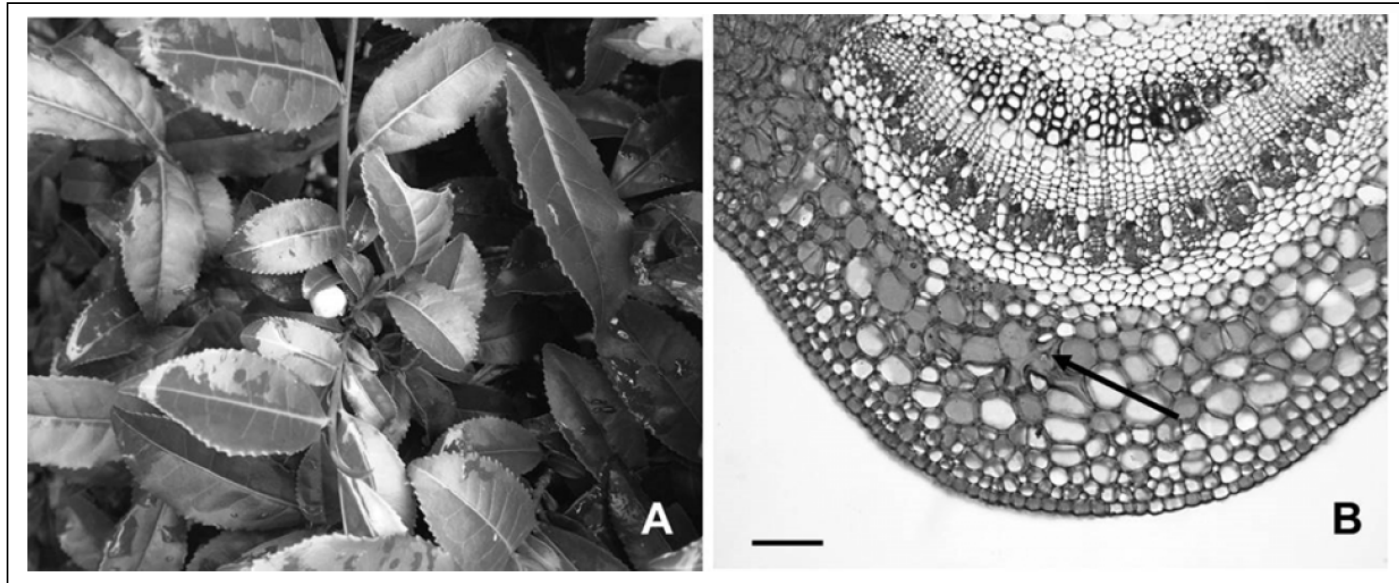

Figure 1 - Characters of leaf of Camellia sinensis: (A) fresh tea leaves of the plant that was used to collection; (B) midrib in the transverse view showing sclereid (arrow). Scale bar, $40 \mu \mathrm{m}$.

contributor to its aroma. They also verified that the volatile compounds linalool and nonanal, both reported in our samples, have been characterized as aroma-active compounds, which may contribute to floral or fruity odors in green tea infusions.

LEE et al. (2013) also reported the presence of linalool and nonanal in green teas. These substances, among others, could be considered key aromatic components, contributing to the sensorial quality of the product, according to these authors.

YANG et al. (2018) also studied the volatile profile of green tea and, as in our research aldehydes were present in a high proportion. As in the present research, volatile compounds such as heptanal, benzaldehyde, (E,E)-2,4-heptadienal and (E)-2-nonenal were reported (Table 2). The aldehydes, originated from thermal Strecker oxidative degradation of amino acids and fatty acids, play an important role on the entire odor because of their relatively low odor threshold values. According to these authors, benzaldehyde, which was present in all samples in our study, is typically described as fragrant, sweet, and having an almond aroma.

Benzaldehyde was also reported in the study conducted by LEE et al. (2013). These authors attributed to this compound a dominantly sweet aroma of freshly crushed almonds, typically used in artificial cherry flavorings. According to them, benzaldehyde has been identified in green tea by many other researchers, when evaluating samples from the Azores, China, Japan, Korea and Taiwan.

Hexanal, trans-2-octenal, trans-2,4heptadienal, cis-2,4-heptadienal, $\beta$-cyclocitral, $\beta$-ionone and other aromatic volatiles compounds have their levels greatly increased during the storage of black teas. These changes in volatiles can be used as indicators of tea aroma quality and to distinguish teas with different periods of storage (SPRINGETT et al., 1994).

According to ZHENG et al. (2016) during storage of low quality green tea containing shoots, stems and branches, an increase in some volatile compounds, such as (E,E)-2,4-heptadienal, was observed. They also have verified a slight increase of ionone derivatives, such as $\alpha$-ionone. In this research, trans-2-octenal, (E,E)-2,4-heptadienal and $\alpha$-ionone were major compounds that were present in all samples, except (E,E)-2,4-heptadienal, which was not present in 8 of the samples (Table 2).

Thermal degradation and solar drying are non-enzymatic ways for the formation of green tea aromas. $\beta$-ionone, 5,6-epoxy- $\beta$-ionone, nerolidol, and dihydroactinidiolide are responsible for the high concentration of flavors in green tea (HO et al., 2015). Dihydroactinidiolide was identified in all samples and as one of the major compounds.

Green tea contains several phenolic compounds such as anethole and eugenol that contribute to the tea flavor in addition to therapeutic properties. Anethole is widely used as a flavoring substance, contributing to the odor and flavor of anise and fennel. Eugenol acts as an antioxidant and an anti-inflammatory agent. It inhibits lipid-peroxidation, and can treat many diseases caused by the presence of hydroxyl radicals, such as atherosclerosis, cancer and neurological disorders (CHAINY et al., 2000; KIM et al., 2003). In addition, both $\alpha$-terpineol and eugenol have been used as natural antifungal agents (PARK et al. 2007; PARK et al., 2009). 
Table 2 - Major compounds obtained by the herb Camellia sinensis marketed in fairs and markets of Belo Horizonte-MG, Brazil, by SPME and GC-MS.

ald benzaldehyde (959); ${ }^{\mathrm{t}}$ limonene (1031); ${ }^{\text {alc }}$ benzyl alcohol (1036); ${ }^{\text {ald }}$ phenylethanal (1046); ${ }^{\mathrm{t}}$ canphenylone (1055); ${ }^{\text {ald }}(\mathrm{E})-2-\mathrm{octenal}(1059)$; ${ }^{\text {alc }} 3$ nonin-2-ol (1065); 'tinalool oxide (1074); ${ }^{\mathrm{k}}(3 \mathrm{E}, 5 \mathrm{E})-3,5$-octadien-2-one (1092); ${ }^{\mathrm{alc}}$ 2-phenylethanol (1112); ${ }^{\mathrm{t}}$ isopulegol (1151); ${ }^{\mathrm{t}}$ epoxy linalool (1167); ${ }^{\mathrm{t}} \alpha$-terpineol (1181); ${ }^{\mathrm{t}} \beta$-ciclocitral (1207); $\gamma$ - butylbutyrolactone (1239); ${ }^{\text {alc }}(\mathrm{E})$-2-decenol (1241); ${ }^{\mathrm{t}}$ citral (1250); ${ }^{\mathrm{h}}$ anethole (1263); ${ }^{\mathrm{n}}{ }_{\text {indole }}$

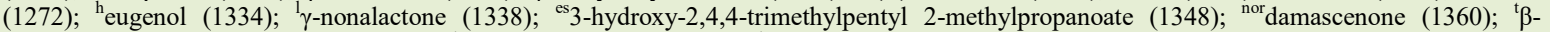
caryophyllene (1396); ${ }^{\text {nor }} \alpha$-ionone (1402); ${ }^{1}$ dihydroactinidiolide (1513); ${ }^{\mathrm{k}} 6,10,14$-trimethyl-2-pentadecanone (1815); ${ }^{\mathrm{nc}}$ caffeine (1820). ald 4-pentenal (692)

ald $(2 \mathrm{E})$-2-pentenal (738) $1-3 ; 5 ; 7-15 ; 17-24 ; 26 ; 27 ; 30 ; 31^{\mathrm{S}}$

et 3 -(allyloxy)-2-methyl-1-propene (771)

ald 2-methyl-4-pentenal (788) $1-14 ; 16-19 ; 21-30 ; 31^{\mathrm{S}}$

ald (E)-2-hexenal (841)

${ }^{\text {alc }}(3 \mathrm{E})-3$-hexenol (843)

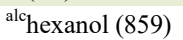

${ }^{k}$ 5-methyl-3-methylene-5-hexen-2-one (877)

ald heptanal (894)

${ }^{\text {alc }}$ (2E)-2-hexen-4-nol (904)

f,7-dimethyloxepine (933)

ald (E,E)-2,4-heptadienal (947) $1 ; 4 ; 6-10 ; 12 ; 14 ; 16-23 ; 25-28$

$1-57-14 ; 16 ; 18-20 ; 22-24 ; 26-30 ; 31^{\mathrm{S}}$

$1-2 ; 5-6 ; 8-14 ; 16-27 ; 218-30 ; 31^{\mathrm{S}}$ $1 ; 3 ; 46-1417 ; 19 ; 20 ; 23-30 ; 31^{\mathrm{S}}$ $1 ; 3-5 ; 7-14 ; 16-23 ; 25-28 ; 30 ; 31^{\mathrm{S}}$

${ }^{\text {alc }}$ heptanol (970)

${ }^{\text {alc }}(2 \mathrm{E})-2$-ethyl-2-hexenol (980)

${ }^{\mathrm{k}}$ 6-methyl-6-hepten-2-one (988)

ald octanal (1004)

ald $(\mathrm{E}, \mathrm{E})-2,4$-octadien-1-al (1012)

ald 3-methyl-3-cyclohexene-1-carbaldehyde (1019)

h5,6-diethyl-cyclohexa-1,3-diene (1026)

ald 2,6-dimethyl-3-cyclohexene-1-carbaldehyde (1049)

alc 1,2 -dipropylene glycol (1079)

alc 3-octen-1-ol (1085)

tinalool (1100)

${ }^{\text {ald }}$ nonanal (1104)

alc3,4-dimethylcyclohexanol (1107)

${ }^{\mathrm{t}}$ Isopinocarveol (1135)

h 2 -methyldecahydronaphthalene (1150)

ald (E)-2-nonenal (1153)

$10 ; 12-14 ; 16-18 ; 20 ; 23-27 ; 29 ; 30 ; 31^{\mathrm{S}}$

terpinen-4-ol (1170)

haphthalene (1174)

$1 ; 2 ; 4-14 ; 16-24 ; 26-30 ; 31^{\mathrm{S}}$

$1 ; 3 ; 6 ; 8-12 ; 16-20 ; 23 ; 24 ; 26-30 ; 31^{\mathrm{S}}$

$$
1-14 ; 16-30
$$

$3-6 ; 8-10 ; 12 ; 14 ; 16-23 ; 26-30 ; 31^{\mathrm{S}}$

$1 ; 2 ; 5-10 ; 12-14 ; 16-19 ; 21-13 ; 26-30 ; 31^{\mathrm{S}}$

$1-3 ; 6-14 ; 17 ; 19-21 ; 23 ; 24 ; 26 ; 28 ; 30 ; 31^{\mathrm{S}}$ $1-30 ; 31^{\mathrm{S}}$

$1-14 ; 16-30 ; 31^{\mathrm{S}}$ $1-30 ; 31^{\mathrm{S}}$

$1-14 ; 16-30$

$3 ; 7-13 ; 16-18 ; 20-25 ; 28-30$

$2 ; 6-14 ; 18-24 ; 26-30$

$1 ; 3 ; 5-13 ; 15-30$

$1 ; 3 ; 4 ; 6 ; 8-14 ; 16 ; 17 ; 19-21 ; 23-25 ; 27-30$

$3-20 ; 23-30 ; 31^{\mathrm{S}}$

$3 ; 5-15 ; 17-27 ; 29 ; 30$ $2-5 ; 7-30 ; 31^{\mathrm{S}}$

$1 ; 3-14 ; 16-19 ; 21-30 ; 31^{\mathrm{S}}$

$1-3 ; 5-12 ; 14-30 ; 31^{\mathrm{S}}$

$1-10 ; 12-14 ; 16-22 ; 24-30 ; 31^{\mathrm{S}}$

$3-5 ; 7 ; ; 9-14 ; 16-21 ; 23-30 ; 31^{\mathrm{S}}$

$1 ; 3 ; 4 ; 7-14 ; 16-24 ; 26 ; 28-30 ; 31^{\mathrm{S}}$

$1 ; 3-9 ; 11-14 ; 16-24 ; 26-30 ; 31^{\mathrm{S}}$

$2-7 ; 9-13 ; 16-21 ; 23-30 ; 31^{\mathrm{s}}$

$1 ; 2 ; 4-12 ; 14 ; 16-30 ; 31^{\mathrm{S}}$

$3 ; 4 ; 6-9 ; 11-13 ; 16-30$

k2- (2-butynyl) cyclohexanone (1269)

h 4-sec-butylphenol (1299)

t8-hydroxylinalool (1364)

tdihydrocarvyl acetate (1368)

htetradecane (1372)

tetrahydrogeranil acetone (1378)

$4 ; 6-12 ; 14 ; 16-23 ; 25-30 ; 31^{\mathrm{S}}$

$1 ; 3 ; 5-12 ; 14 ; 16 ; 19-30$

$1-4 ; 6-12 ; 14-27 ; 29 ; 30 ; 31^{\mathrm{S}}$

alc 2 -undecen-1-ol (1382)

tnerylacetone (1426)

${ }^{\text {nor }} \beta$-ionone epoxyde (1463)

${ }^{\mathrm{k}} 8 \mathrm{a}-\mathrm{methyl}$ hexahydro-1.8(2H, 5H) -naphthalenedione (1506)

tcaryophyllene oxide (1538)

$1-4 ; 6-10 ; 12-14 ; 16-18 ; 20-22 ; 24-30$

$1-4 ; 6-15 ; 17-26 ; 28-30 ; 31^{\mathrm{S}}$

$2-4 ; 6-12 ; 14-18 ; 20-28 ; 30 ; 31^{\mathrm{S}}$

$1-4 ; 6 ; 8-12 ; 14-19 ; 21 ; 22 ; 24-30$

$1 ; 3 ; 4 ; 6-26 ; 28-30 ; 31^{\mathrm{S}}$

$3-14 ; 16-22 ; 24-26 ; 28-30 ; 31^{\mathrm{S}}$

${ }^{a}$ Compounds are listed in order of retention time. ${ }^{\mathrm{b}}$ Method of identification, identification by comparison with mass spectra in NIST 98 library and identification by retention index and comparison with those reported in the literatures. RI, retention indices as determined on HP-5MS column using the homologous series of n-alkanes. ${ }^{\text {alc }}$ Alcohols; ${ }^{\text {ald }}$ Aldehydes; ${ }^{\text {es Esters; }}{ }^{\text {et }}$ Ether; ${ }^{\text {ca }}$ Carboxylic acid; ${ }^{\mathrm{f}}$ Furan; ${ }^{\mathrm{h}} \mathrm{Hydrocarbons}$; ${ }^{\mathrm{k}} \mathrm{Ketone}$;

${ }^{1}$ Lactones; ${ }^{\mathrm{t}}$ Terpene; ${ }^{\mathrm{nc}}$ Nitrogen compounds; ${ }^{\text {nor }}$ Norisoprenoids; ${ }^{\circ}$ Others; $1-30=$ commercial samples; $31=$ plant in natura. 
Alcohols were the third major chemical group reported in our study (Table 2). The research conducted by YANG et al. (2018) has identified benzyl alcohol as one of the most abundant compounds in green teas. This substance was found in all studied samples in the present research. Benzyl alcohol has been reported in various types of tea, and gives a mild sweet and roasted odor to green teas. 2-phenylethanol was present in all green tea samples. The compound has a floral rose odor (LEE et al., 2013).

Caffeine and indole, two nitrogen compounds, were also present in all analyzed samples (Table 2). Caffeine is usually related to the taste of tea, but it contributes little to its aroma (YANG et al., 2018). Indole can be reported in high levels in tea beverages, and it was described by ZHENG et al. (2016) as being an aroma-active compound of deep-steamed green teas.

Three norisoprenoids, $\alpha$-ionone, $\beta$-ionone epoxyde and damascenone, were found in this study, being $\alpha$-ionone and damascenone present in all samples (Table 2). ZHENG et al. (2016) reported that ionone derivatives, such as $\alpha$-ionone, which are formed by oxidation of carotenoids, may increase slightly during green tea storage. The $\alpha$-ionone has a woody, violetlike odor and is commonly reported in Japanese green teas (LEE et al., 2013). Carotenoids are important precursors of tea volatile compounds, especially the $\mathrm{C} 9$ - to $\mathrm{C} 13$-aromas. Ionone and damascone are $\mathrm{C} 13$ carotenoid-derived compounds that constitute an essential aroma note in some teas. It has been reported that the presence of norisoprenoids, including $\beta$-ionone, $\alpha$-ionone and $\beta$-damascone may be associated with the fermentation and aging processes of beverages, including teas and wines (HO et al., 2015).

The chromatographic analysis of $C$. sinensis also revealed thirty compounds present in all the analysed samples, namely: benzaldehyde, 6-methyl-6-hepten-2one, (E,E)-2,4-octadien-1-al, limonene, benzyl alcohol, phenylethanal, canphenylone, (E)-2-octenol, 3-nonin2-ol, linalool oxide, (3E,5E)-3,5-octadien-2-one, 2-phenylethanol, isopulegol, epoxy linalool, $\alpha$-terpineol, $\beta$-ciclocitral, $\gamma$-butylbutyrolactone, (E)-2-decenol, citral, anethole, indole, eugenol, $\gamma$-nonalactone, 3-hydroxy2,4,4-trimethylpentyl 2-methylpropanoate, damascenone, $\beta$-caryophyllene, $\alpha$-ionone, dihydroactinidiolide, 6,10,14-trimethyl-2-pentadecanone and caffeine (Table 2). These compounds can be considered potential chemical markers of this plant species and more studies are necessary to investigate and characterize them. The identification of these markers is important for monitoring the authenticity of the marketed species, which would allow a greater quality control and the ability to monitor the adulteration of medicinal plants obtained by consumers. Commercial samples were probably submitted to different drying processes, as well as the leaves of the plant should present different maturation periods. Even with these possible variations, thirty characteristic volatile compounds of the species were identified in the reference sample (sample collected and deposited in the herbarium) and in all commercial samples, confirming their authenticity.

\section{Microbiological analysis}

In this study, the methodology used for microbiological analysis was based on the methods proposed by the FARMACOPÉIA BRASILEIRA (2010), that establishes specifications for plant material that will be submitted to hot extractive processes, as follows: maximum limit of $10^{7} \mathrm{CFU} / \mathrm{g}$ for counts of mesophilic bacteria, $10^{4} \mathrm{CFU} / \mathrm{g}$ for molds and yeasts, $10^{2} \mathrm{CFU} / \mathrm{g}$ for Escherichia coli and absence of Salmonella spp., both in $1 \mathrm{~g}$ of the plant material.

Our data showed that among the 30 samples of $C$. sinensis analyzed, only five (16.6\%) were not in accordance with the limits established for counts of mesophilic bacteria (Table 1). Considering also the limits admitted by the FARMACOPÉIA BRASILEIRA (2010) for molds and yeasts, only four samples $(13.3 \%)$ were in disagreement with the specification, while 22 samples $(73.3 \%)$ exceeded the limit specified for $E$. coli. None of the analyzed samples contained Salmonella spp. (Table 1). The presence of these microorganisms, beyond the limits established in the legislation, may indicate incorrect manipulation, as well as inadequate hygienic conditions in the productive and storage processes.

Contamination with molds and yeasts, as well as mesophilic bacteria, may indicate inadequate storage of the raw material or final product, exposing the material to unhygienic and humid conditions. In addition to these factors, these products may have been improperly handled or placed in contact with dirty equipment and some external contaminated plants and/or environments. According to MARTINS et al. (2001), during the regular production process (drying, cutting, packing and storing) and distribution, these products are not submitted to any kind of control that could prevent microbial contamination and growth. Converesely, there is still a lack of knowledge considering the microbiological quality of such products in Brazil. After an evaluation of microbial contamination in vegetal drugs according to the FARMACOPÉIA BRASILEIRA (2010) specifications for products of oral use, BUGNO et al. (2005) reported that $81.5 \%$ of the analyzed samples, including $C$. 
sinensis, could be considered unsatisfactory because of the presence of at least one of the pathogenic species.

Our data showed that microbiological quality control is important for monitoring possible contamination of herbal products, ensuring quality and safety to the final consumer. This study also highlighted the necessity of applying good manufacturing and hygiene practices during all stages, from the postharvest process to retail and use. These practices help to prevent cross-contamination and microbial growth in these products, which may affect their final quality.

\section{CONCLUSION}

The interest in the use of plant products has increased in the last few years due to the fact that many of them have medicinal properties demonstrated by scientific studies. In this context, there is a great concern about the quality of the available products on the market, since they are frequently consumed without medical prescription. In addition to this, a large part of the population use herbal drugs as an alternative therapy in primary health care.

Our data showed that greater attention is needed both in production and in strict monitoring to ensure the quality of commercial medicinal plants of Camellia sinensis in Brazil. The deviations in the physical-chemical and microbiological parameters reported in the present study can be avoided if there is a more effective assessment ofe quality of these products, in order to ensure their safety and efficacy. Therefore, the identification of volatile compounds present in different samples of Brazilian green teas by GC-MS may represent an important technique for monitoring the authenticity of the marketed species, allowing a greater quality control and the ability to verify the adulteration of the products obtained by consumers. Our data showed that commercially available samples of $C$. sinensis presented 30 characteristic volatile compounds in common with the reference sample (sample collected and deposited in the herbarium), confirming their authenticity. Our results open perspectives for future research of possible indicators and markers that may serve for quality control of Brazilian marketed green teas. Thus, additional studies are necessary to better characterize their volatile profile.

\section{ACKNOWLEDGMENTS}

The authors would like to thank to Centro Federa de Educação Tecnológica de Minas Gerais (CEFET-MG) for the opportunity and trust in performing the work and Coordenação de Aperfeiçoamento de Pessoal de Nível Superior (CAPES), for the scholarship support.

\section{DECLARATION}

OF

CONFLICTING INTERESTS

The authors declare no conflict of interest. The founding sponsors had no role in the design of the study; in the collection, analyses, or interpretation of data; in the writing of the manuscript, and in the decision to publish the results.

\section{AUTHORS' CONTRIBUTIONS}

The authors contributed equally to the manuscript.

\section{REFERENCES}

ARAÚJO, A. A. S. et al. Determination of humidity and ash content of guarana commercial samples using conventional method and thermal analysis. Brazilian Journal of Pharmaceutical Sciences, v.42, n.2, p.269-277, 2006. Available from: <http:// www.scielo.br/scielo.php? script $=$ sci_arttext\&pid $=\mathrm{S} 1516$ 93322006000200013\&lng=en\&nrm=iso $>$. Accessed: Jun. 18, 2018. doi: 10.1590/S1516-93322006000200013.

BRANDÃO, M. G. L. et al. Other medicinal plants and other botanical products from the Brazilian Official Pharmacopoeia. Revista Brasileira de Farmacognosia, v.6, p.408-420, 2006. Available from: $<\mathrm{http}$ //www.scielo.br/scielo.php?script=sci arttext\&pid=S0102-695X2008000100022>. Accessed: Jun. 18, 2018. doi: 10.1590/S0102-695X2008000100022.

BUGNO, A. et al. Evaluation of microbiological contamination of crude herbal drugs. Brazilian Journal of Pharmaceutical Sciences, v.41, p.491-497, 2005. Available from: <https:// www.researchgate.net/publication/242630170_Avaliacao_da contaminacao_microbiana_em_drogas_vegetais $>$. Accessed: Jun. 18, 2018. doi: $10.1590 / \mathrm{S} 1516-\overline{9} 3322005000400012$.

CHAINY, G. B. et al. Anethole blocks both early and late cellular responses transduced by tumor necrosis factor: effect on NF-[kappa] B, AP-1, JNK, MAPKK and apoptosis. Oncogene, v.19, p.2943-2950, 2000. Available from: <https://www.nature.com/articles/1203614. Accessed: Jun. 18, 2018. doi: 10.1038/sj.onc.1203614>.

DUARTE, M. R.; MENARIM, D. O. Leaf and stem anatomical morpho-diagnosis of Camellia sinensis (L.) Kuntze, Theaceae. Revista Brasileira de Farmacognosia, v.6, p.545-551, 2006. Available from: $<$ http://www.scielo.br/scielo.php?script $=$ sci arttext\&pid=S0102-695X2006000400018>. Accessed: Jun. 18, 2018. doi: 10.1590/S0102-695X2006000400018.

EKAYANTI, M. Pharmacognostic and phytochemical standardization of white tea leaf (Camellia sinensis L. Kuntze) ethanolic extracts. Pharmacognosy Journal, v.9, n.2, p.221226, 2017. Available from: <http://www.phcogj.com/article/255>. Accessed: Jun. 18, 2018. doi:10.5530/pj.2017.2.37.

FARMACOPÉIA BRASILEIRA. Agência Nacional de Vigilância Sanitária, 5. ed. São Paulo: Atheneu, 2010. v.2, 904p. Available from: <http://portal.anvisa.gov.br/documents/ $33832 / 260079 / 5 \% \mathrm{C} 2 \% \mathrm{AA}+\mathrm{edi} \% \mathrm{C} 3 \% \mathrm{~A} 7 \% \mathrm{C} 3 \% \mathrm{~A} 3 \mathrm{o}+-$ +Volume+1/4c530f86-fe83-4c4a-b907-6a96b5c2d2fc $>$. Accessed: Jun. 18, 2018.

GUPTA, D.; KUMAR, M. Evaluation of in vitro antimicrobial potential and GC-MS analysis of Camellia sinensis and Terminalia arjuna. 
Biotechnology Reports, v.13, p.19-25, 2017. Available from: $<$ https:// www.sciencedirect.com/science/article/pii/S2215017X16300960>. Accessed: Jun. 18, 2018. doi: 10.1016/j.btre.2016.11.002.

HO, C. T. et al. Tea aroma formation. Food Science and Human Wellness, v.4, p.9-27, 2015. Available from: <https:/www researchgate.net/publication/275060277_Tea_aroma_formation $>$. Accessed: Jun. 18, 2018. doi: 10.1016/j.fshw.2015.04.001.

HUANG, J. et al. Green Tea Polyphenol EGCGAlleviates Metabolic Abnormality and Fatty Liver by Decreasing Bile Acid and Lipid Absorption in Mice. Molecular Nutrition Food Research, v.62, p.1-12, 2018. Available from: <https://onlinelibrary.wiley.com/ doi/epdf/10.1002/mnfr.201700696> . Accessed: Jun. 18, 2018. doi: $10.1002 / \mathrm{mnfr} .201700696$.

JENSEN, W. A. Botanical Histochemistry: Principles and Practice, San Francisco: WH Freeman and Co, 1962. 408p.

KIM, S. S. et al. Eugenol suppresses cyclooxygenase-2 expression in lipopolysaccharide-stimulated mouse macrophage RAW264.7 cells. Life Science, v.73, n.3, p.337-348, 2003. Available from: $<$ https://eurekamag.com/pdf/003/003756761.pdf $>$. Accessed: Jun. 18, 2018. doi: 10.1016/S0024-3205(03)00288-1.

LEE, J. et al. Volatile aroma compounds in various brewed green teas. Molecules, v.18, p.10024-1004, 2013. Available from: $<$ http://www.mdpi.com/1420-3049/18/8/10024>. Accessed: Jun. 18, 2018. doi:10.3390/molecules 180810024 .

LI, Y.F. et al. A comparative analysis of chemical compositions in Camellia sinensis var. sinensis Kurihara, a novel Chinese tea, by HPLC and UFLC-Q-TOF-S/MS. Food Chemistry, v.216, p.282-288, 2017. Available from: <https://www.sciencedirect .com/science/article/pii/S030881461631247X?via\%3Dihub>. Accessed: Jun. 18, 2018. doi: 10.1016/j.foodchem.2016.08.017.

LIN, J. et al. Volatile profile analysis and quality prediction of Longjing tea (Camellia sinensis) by HS-SPME/GC-MS. Journal of Zhejiang University-SCIENCE B, v.13, n.12, p.972-980, 2012. Available from: $<$ https://www.ncbi.nlm.nih.gov/pmc/articles/ PMC3520451/>. Accessed: Jun. 18, 2018. doi:10.1631/jzus. B1200086

LV, H. P. et al. Aroma characterisation of Puerh tea using headspace-solid phase microextraction combined with $\mathrm{GC} /$ MS and GC-olfactometry. Food Chemistry, v. 130, p.10741081, 2012. Available from: <https://www.researchgate.net/ publication/257163897_Aroma_characterisation_of_Puerh_tea_ using_headspace-solid_phase_microextraction_combined_with GCMS_and_GC-olfactometry $>$. Accessed: Jul. 03, 2018. do $\overline{\text { : }}$ 10.1016/j.foodchem.2011.07.135.

MARTINS, H. M. et al. Evaluation of microbiological quality of medicinal plants used in natural infusions. International Journal of Food Microbiology, v.68, p.149-153, 2001. Available from: $<$ http://www.ncbi.nlm.nih.gov/pubmed/11545215>. Accessed: Jul. 03, 2018. doi: 10.1016/j.foodchem2011.07.135.10.1016/S01681605(01)00480-9. Accessed: Jul. 03, 2018.

PARK, M. J. et al. Antifungal activities of the essential oils in Syzygium aromaticum (L.) Merr. Et Perry and Leptospermum petersonii Bailey and their constituents against various dermatophytes. Journal Microbiology, v.45, n.4, p.460-465, 2007. Available from: <http:/www.jonnsaromatherapy.com/
pdf/Park_Antifungal_Activities_of_Essential_Oils_of_Clove_ Manuka_2007.pdf>. Accessed: Jun. 18, 2018.

PARK, M. et al. Effect of citral, eugenol, nerolidol and $\alpha$-terpineol on the ultrastructural changes of Trichophyton mentagrophytes. Fitoterapia, v.80, n.5, p.290-296, 2009. Available from: <https:// www.ncbi.nlm.nih.gov/pubmed/19345255>. Accessed: Jul. 03, 2018. doi: 10.1016/j.fitote.2009.03.007.

PIMENTEL-SOUZA, J. D. R. et al. Functional quality of commercial green tea. Revista de Nutrição, v.25, n.6, p.753763, 2012. Available from: <http://www.scielo. br/pdf/rn/ v25n6/07.pdf $>$. Accessed: Jul. 03, 2018. doi: 10.1590/S141552732012000600007.

PRIPDEEVECH, P.; MACHAN, T. Fingerprint of volatile flavour constituents and antioxidant activities of teas from Thailand. Food Chemistry, v.125, p.797-802, 2011. Available from: $<$ www.researchgate.net/publication/229252177_Fingerprint_of volatile_flavour_constituents_and_antioxidant_activities_of teas_from_Thailand $>$. Accessed: Jul. 03, 2018. doi: 10.1016/j. foodchem. 2010.09 .074

SILVA, B. C. et al. Quality evaluation of samples of Camellia sinensis (L.) Kuntze (Theaceae) commercialized in the city of Araras-SP. Revista de Ciências Farmacêuticas Básica e Aplicada, v.34, n.2, p.245-250, 2013. Available from: <http://serv-bib.fcfar. unesp.br/seer/index.php/Cien_Farm/article/viewFile/2119/1407>. Accessed: Jul. 03, 2018.

SPRINGETT, M. B. et al. The effect of packaging conditions and storage time on the volatile composition of Assam black tea leaf. Food Chemistry, v.49, p.393-398, 1994. Available from: <http:// www.sciencedirect.com/science/article/pii/0308814694900108>. Accessed: Jul. 03, 2018. doi: 10.1016/0308-8146(94)90010-8.

THITIMUTA, S. et al. Camellia sinensis L. Extract and its potential beneficial effects in antioxidant, anti-inflammatory, anti-hepatotoxic, and anti-tyrosinase activities. Molecules, v.22, n.3, p.401-414, 2017. Available from: <http://www.mdpi. com/1420-3049/22/3/401>. Accessed: Jul. 03, 2018. doi: 10.3390/ molecules 22030401 .

UENOJO, M. et al. Carotenoids: properties, applications and biotransformation in flavor compounds. Química Nova, v.30, n.3, p.616-622, 2007. Available from: <http:/quimicanova.sbq.org.br/ imagebank/pdf/Vol30No3_616_21-RV05523.pdf $>$. Accessed: Jul. 03, 2018

YANG, Y. Q. et al. Characterization of the volatile components in green tea by IRAE-HS-SPME/GC-MS combined with multivariate analysis. Plos One, v.13, n.3, p.e0193393, 2018. Available from: <http:// journals.plos.org/plosone/article?id=10.1371/journal.pone.0193393>. Accessed: Jul. 03, 2018. doi: 10.1371/journal.pone.0193393.

ZHAO, M. et al. Determination and comparison of $\gamma$-aminobutyric acid (GABA) content in pu-erh and other types of Chinese tea. Journal of Agricultural and Food Chemistry, v.59, n.8, p.36413648, 2011. Available from: $<$ https://pubs.acs.org/doi/abs/10.1021/ jf104601v>. Accessed: Jul. 03, 2018. doi: 10.1021/jf104601v.

ZHENG, X. Q. et al. Recent Advances in Volatiles of Teas. Molecules, v.21, p338-350, 2016. Available from: < https://www. ncbi.nlm.nih.gov/pubmed/26978340>. Accessed: Jul. 03, 2018. doi: 10.3390/molecules21030338. 